\title{
Matrix Isolation and Computational Study on the Photolysis of $\mathrm{CHCl}_{2} \mathrm{COCl}$
}

\author{
Nobuaki Tanaka \\ Department of Environmental Science and Technology, Faculty of Engineering, Shinshu University, Nagano, \\ Japan \\ Email: ntanaka@shinshu-u.ac.jp
}

Received 24 May 2014; revised 20 June 2014; accepted 15 July 2014

Copyright (C) 2014 by author and Scientific Research Publishing Inc.

This work is licensed under the Creative Commons Attribution International License (CC BY).

http://creativecommons.org/licenses/by/4.0/

c) (i) Open Access

\begin{abstract}
UV light photolysis of dichloroacetyl chloride $\left(\mathrm{CHCl}_{2} \mathrm{COCl}\right)$ has been investigated by infrared spectroscopy in cryogenic $\mathrm{Ar}, \mathrm{Kr}, \mathrm{Xe}$, and $\mathrm{O}_{2}$ matrices. The formation of $\mathrm{CHCl}_{3}$ and $\mathrm{CO}$ was found to be the dominant process over the ketene formation. The $\mathrm{C}-\mathrm{C}$ bond cleaved products $\mathrm{CHCl}_{2}$ and $\mathrm{COCl}$ were also observed. As the number of the chlorine atom substitution to methyl group of acetyl chloride increased, the $C$-C bond cleaved product yield in the triplet state increased, which can be attributed to an internal heavy-atom effect where the intersystem crossing rate was enhanced.
\end{abstract}

\section{Keywords}

Dichloroacetyl Chloride, Photolysis, Cryogenic Matrix

\section{Introduction}

Dichloroacetyl chloride $\left(\mathrm{CHCl}_{2} \mathrm{COCl}\right)$ is known to be produced in the oxidation of chlorinated ethenes [1]-[4]. In the chlorine atom initiated oxidation of chlorinated ethenes, relatively high product yields of chlorinated acetyl chloride were reported by Hasson and Smith [5]. Conformations of $\mathrm{CHCl}_{2} \mathrm{COCl}$ were studied by vibrational spectroscopy [6]-[9], electron diffraction [10], and theoretical method [11]. Two conformers exist in the $\mathrm{CHCl}_{2}$ internal rotation potential: syn conformer having an $\mathrm{H}-\mathrm{C}-\mathrm{C}=\mathrm{O}$ dihedral angle of $0^{\circ}$ and gauche conformer having a non-zero value of the dihedral angle. As for the photolysis of chlorinated acetyl chloride in rare gas matrix, one chlorine atom substitution to methyl group of acetyl chloride opened the additional reaction paths in the $\mathrm{T}_{1}$ state [12] [13]. Without chlorination the ketene $\cdots \mathrm{HCl}$ complex was exclusively produced in the $\mathrm{S}_{0}$ state after the internal conversion from the $\mathrm{S}_{1}$ state [14] [15]. In the $\mathrm{CCl}_{3} \mathrm{COCl}$ photolysis in an Ar matrix, the C-C bond cleavage was found to be the major reaction path [16].

In the present study, the UV light photolysis of $\mathrm{CHCl}_{2} \mathrm{COCl}$ was investigated in cryogenic $\mathrm{Ar}, \mathrm{Kr}, \mathrm{Xe}$, and $\mathrm{O}_{2}$ 
matrices with the aid of the calculation using the B3LYP and MP2 methods to clarify how the two chlorine atom substitutions affect the reaction mechanism.

\section{Experimental}

Light irradiation was performed using a low pressure mercury arc lamp (HAMAMATSU L937-04, $\lambda>253.7$ $\mathrm{nm}$ ). IR spectra were measured in the range $4000-700 \mathrm{~cm}^{-1}$ with $1.0 \mathrm{~cm}^{-1}$ resolution by a SHIMADZU 8300A Fourier transform IR spectrometer with a liquid-nitrogen-cooled MCT detector. Each spectrum was obtained by scanning over 128 times. A closed-cycle helium cryostat (Iwatani M310/CW303) was used to control the temperature of the matrix.

Argon (Nippon Sanso, 99.9999\%), krypton (Taiyo Sanso), xenon (Nippon Sanso), and $\mathrm{O}_{2}$ (Okaya Sanso) were used without further purification. Dichloroacetyl chloride (Wako Pure Chemicals) was used after freezepump-thaw cycling at $77 \mathrm{~K}$. Chloroform (Wako Pure Chemicals) was used as an authentic sample for product identification. Samples were deposited on a CsI window at $6 \mathrm{~K}$.

For product identification and energetic consideration, molecular orbital calculation was utilized. Geometry optimizations were performed using the second-order Møller-Plesset theory (MP2) and density functional theory (B3LYP [17] [18], CAM-B3LYP [19], and M06-2X [20]) with the 6-311++G(3df,3pd) and aug-cc-pV(T+d)Z basis sets. Harmonic vibrational frequency calculation was performed to confirm the predicted structures as local minima and to elucidate zero-point vibrational energy corrections (ZPE). The vertical transition energy was calculated at the SAC-CI/D95+(d,p) level based on the structures optimized at the CCSD/D95+(d,p) level. All calculations were performed using Gaussian 09 [21].

\section{Results and Discussion}

\section{1. $\mathrm{CHCl}_{2} \mathrm{COCl} / \mathrm{Ar}$}

A mixture of $\mathrm{CHCl}_{2} \mathrm{COCl} / \mathrm{Ar}$ was deposited on a CsI window with a ratio of $\mathrm{CHCl}_{2} \mathrm{COCl} / \mathrm{Ar}=1 / 1000$. In the infrared spectrum obtained after deposition, two conformers, gauche- and syn- $\mathrm{CHCl}_{2} \mathrm{COCl}$ were distinguished by the $\mathrm{C}=\mathrm{O}$ stretching vibration bands at 1816 and $1784 \mathrm{~cm}^{-1}$, respectively [8] [9]. Figure 1(a) shows the infrared difference spectrum obtained upon $\lambda>253.7 \mathrm{~nm}$ irradiation of a matrix $\mathrm{CHCl}_{2} \mathrm{COCl} / \mathrm{Ar}$ for $60 \mathrm{~min}$. The positive and negative bands indicate the growth and depletion, respectively, during the irradiation period. Table 1 lists the observed wavenumbers of the growth bands. In the CO stretching region, a strong band observed at $2138 \mathrm{~cm}^{-1}$ assignable to the CO stretching continued to grow during the prolonged irradiation period. A band at $2155 \mathrm{~cm}^{-1}$ showed growth and decay behavior accompanied with the bands at 1293 and $934 \mathrm{~cm}^{-1}$, whose frequencies are consistent with those of $\mathrm{CCl}_{2}=\mathrm{C}=\mathrm{O}$ observed in the $\mathrm{CCl}_{3} \mathrm{COCl}$ photolysis in $\mathrm{Ar}$ [16]. The bands at 2844 and $2836 \mathrm{~cm}^{-1}$ were assigned to the stretching vibration of $\mathrm{HCl}$ complexed with the $\mathrm{CCl}_{2}=\mathrm{C}=\mathrm{O}$. With the different growth rate from those of $\mathrm{CO}$ and $\mathrm{CCl}_{2}=\mathrm{C}=\mathrm{O}$, three bands at 2150, 1297 and $1113 \mathrm{~cm}^{-1}$ showed continuous growth which are assignable to the $\mathrm{C}=\mathrm{O}$ stretching, $\mathrm{C}=\mathrm{C}$ stretching, and $\mathrm{C}-\mathrm{H}$ in-plane bending vibrations of $\mathrm{CHCl}=\mathrm{C}=\mathrm{O}$, respectively [12]. The $\mathrm{C}-\mathrm{Cl}$ stretching band observed in the photolysis of $\mathrm{CH}_{2} \mathrm{ClCOCl}$ in $\mathrm{Ar}$ was difficult to be discerned due to the overlapping with the strong depletion band of syn- $\mathrm{CHCl}_{2} \mathrm{COCl}$. A band at $1878 \mathrm{~cm}^{-1}$ was assigned to the CO stretching vibration of $\mathrm{COCl}$ [22]. Photolysis counterpart of $\mathrm{COCl}, \mathrm{CHCl}_{2}$, showed the $\mathrm{C}-\mathrm{H}$ bending and $\mathrm{CCl}_{2}$ antisymmetric stretching vibrations at 1219 and $898 \mathrm{~cm}^{-1}$, respectively [23]. Prolonged irradiation caused the depletion in intensities of the bands due to $\mathrm{CCl}_{2}=\mathrm{C}=\mathrm{O}$ as shown in Figure 1(b). A band at $1969 \mathrm{~cm}^{-1}$ showing an induction period was assigned to the CO stretching vibration of CCO [24]. A band at $766 \mathrm{~cm}^{-1}$ grew continuously to be the strongest in the spectrum after 360 min irradiation, which was assigned to the $\mathrm{C}-\mathrm{Cl}$ stretching vibration of $\mathrm{CHCl}_{3}$. The $\mathrm{C}-\mathrm{H}$ bending vibration of $\mathrm{CHCl}_{3}$ was observed at 1223 $\mathrm{cm}^{-1}$.

\section{2. $\mathrm{CHCl}_{2} \mathrm{COCl} / \mathrm{Kr}, \mathrm{CHCl}_{2} \mathrm{COCl} / \mathrm{Xe}$}

Figure 2 shows the infrared difference spectra obtained upon $\lambda>253.7 \mathrm{~nm}$ irradiation of the matrix $\mathrm{CHCl}_{2} \mathrm{COCl} / \mathrm{Xe}$. In $\mathrm{Kr}$, similar results were obtained. In addition to the photolysis products in Ar, the products of $\mathrm{Kr}_{2} \mathrm{H}^{+}$and $\mathrm{Xe}_{2} \mathrm{H}^{+}$were observed in $\mathrm{Kr}$ and Xe, respectively [25]. The growth bands at 1814, 1262, 987, and $740 \mathrm{~cm}^{-1}$ in $\mathrm{Kr}$ and 1809, 1259, 984, and $736 \mathrm{~cm}^{-1}$ in Xe were assigned to the $\mathrm{C}=\mathrm{O}$ stretching, $\mathrm{CH}$ bending, C-C stretching, and $\mathrm{CCl}_{2}$ symmetric stretching vibrations of gauche- $\mathrm{CHCl}_{2} \mathrm{COCl}$, respectively [9]. It is controversial 


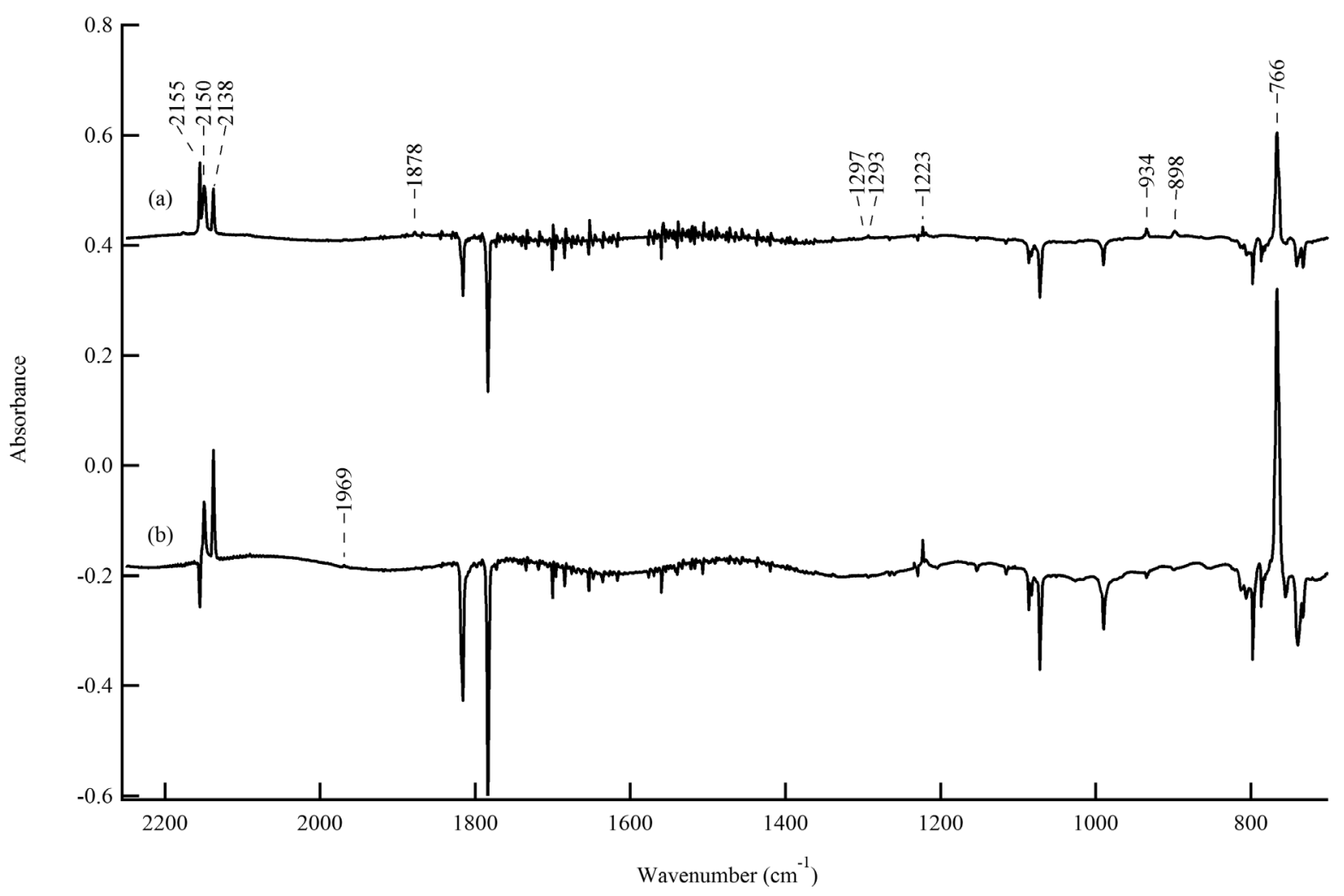

Figure 1. Infrared difference spectra upon $\lambda>253.7 \mathrm{~nm}$ irradiation of the matrix $\mathrm{CHCl}_{2} \mathrm{COCl} / \mathrm{Ar}=1 / 1000$. (a) $60-0 \mathrm{~min}$ and (b) 360 - 60 min.

which of the two conformers is more stable [11]. Table 2 compares the relative electronic energies calculated at the several calculation levels. The barrier height for the conversion from the syn to gauche rotamer is calculated to be approximately $1200 \mathrm{~cm}^{-1}$ in the $\mathrm{S}_{0}$ ground state indicating that the conversion between the syn and gauche rotamers is not expected to occur at $7 \mathrm{~K}$ in the absence of UV irradiation. UV irradiation yielded an increase of the population of the less stable rotamer.

\section{3. $\mathrm{CHCl}_{2} \mathrm{COCl} / \mathrm{O}_{2}$}

In order to clarify the route of the ketenes and $\mathrm{CHCl}_{3}$ formation i.e. the radical or concerted mechanism, the reactive $\mathrm{O}_{2}$ matrix was used. Figure 3 shows the infrared difference spectrum obtained after 480 min irradiation of $\mathrm{CHCl}_{2} \mathrm{COCl}$. The product bands were assigned by comparison with the spectrum observed in the photolysis of the matrix $\mathrm{CCl}_{3} \mathrm{COCl} / \mathrm{O}_{2}$. Due to the photolysis in $\mathrm{O}_{2}$ at $253.7 \mathrm{~nm}$, ozone formation is prominent at $1038 \mathrm{~cm}^{-1}$ $\left(v_{3}\right)$ [26]. Other $\mathrm{O}_{3}$ absorption bands were observed at $2107\left(v_{1}+v_{3}\right)$ and $1101 \mathrm{~cm}^{-1}\left(v_{1}\right)$ [26] [27]. The 2342 and $2276 \mathrm{~cm}^{-1}$ bands are assigned to $v_{3}$ vibrations of ${ }^{12} \mathrm{CO}_{2}$ and ${ }^{13} \mathrm{CO}_{2}$, respectively. The $2037 \mathrm{~cm}^{-1}$ band is attributed to $\mathrm{CO}_{3}$ complexed with $\mathrm{Cl}$ [16]. A broad band at $1436 \mathrm{~cm}^{-1}$ was assigned to $\mathrm{ClOO} v_{1}$ [28]. In $\mathrm{O}_{2}$, compared with the ratio of $\mathrm{CHCl}_{3}$ or $\mathrm{CO}$ absorbance with $\mathrm{CHCl}_{2} \mathrm{COCl}$ absorbance in Figure 1, the $\mathrm{CO}$ and $\mathrm{CHCl}_{3}$ formation was depressed. Formation of $\mathrm{CHCl}_{2}$ and ketenes was negligible. Instead major product was found to be $\mathrm{CO}_{2}$ which would be produced via reactions of $\mathrm{COCl}$ and $\mathrm{CHCl}_{2}$ with $\mathrm{O}_{2}$. These indicate the reaction predominantly proceed by radical mechanism in the photolysis of $\mathrm{CHCl}_{2} \mathrm{COCl}$ similar to that of $\mathrm{CCl}_{3} \mathrm{COCl}$.

\subsection{Reaction Mechanism}

Figure 4 shows the integrated absorbance changes of syn- $\mathrm{CHCl}_{2} \mathrm{COCl}\left(1784 \mathrm{~cm}^{-1}\right)$, gauche- $\mathrm{CHCl}_{2} \mathrm{COCl}(1816$ $\left.\mathrm{cm}^{-1}\right), \mathrm{CHCl}_{3}\left(766 \mathrm{~cm}^{-1}\right), \mathrm{CHCl}=\mathrm{C}=\mathrm{O}\left(2150 \mathrm{~cm}^{-1}\right), \mathrm{CO}\left(2138 \mathrm{~cm}^{-1}\right), \mathrm{CCl}_{2}=\mathrm{C}=\mathrm{O}\left(2155 \mathrm{~cm}^{-1}\right)$, and $\mathrm{CHCl}_{2}(898$ $\mathrm{cm}^{-1}$ ) observed in Ar, where the IR intensities of these absorption bands were calculated to be 283, 242, 320, 618, 80, 621, and $163 \mathrm{~km} \mathrm{~mol}^{-1}$, respectively, at the B3LYP/aug-cc-pV(T+d)Z level. The syn- and gauche- 
Table 1. FTIR spectra of the $\mathrm{CHCl}_{2} \mathrm{COCl}$ photolysis products in the $\mathrm{Ar}, \mathrm{Kr}$, $\mathrm{Xe}$, and $\mathrm{O}_{2}$ matrices.

\begin{tabular}{|c|c|c|c|c|}
\hline \multicolumn{4}{|c|}{ Wavenumber $\left(\mathrm{cm}^{-1}\right)$} & \multirow{2}{*}{ Assignment } \\
\hline $\mathrm{Ar}$ & $\mathrm{Kr}$ & $\mathrm{Xe}$ & $\mathrm{O}_{2}$ & \\
\hline 3112 & & & & $\mathrm{CHCl}=\mathrm{C}=\mathrm{O}$ \\
\hline 3060 & & & & $\mathrm{CHCl}_{3}$ \\
\hline 3054 & & & & $\mathrm{CHCl}_{3}$ \\
\hline $2844 / 2836$ & $2836 / 2827$ & & 2838 & $\mathrm{HCl} \cdots \mathrm{CCl}_{2}=\mathrm{C}=\mathrm{O}$ \\
\hline 2809 & 2809 & & 2807 & $\mathrm{HCl}$ \\
\hline \multirow[t]{3}{*}{2789} & 2788 & & & $\mathrm{HCl}$ \\
\hline & & & 2342 & $\mathrm{CO}_{2}$ \\
\hline & & & 2276 & ${ }^{13} \mathrm{CO}_{2}$ \\
\hline \multicolumn{5}{|l|}{2176} \\
\hline 2155 & $2154 / 2151$ & 2148 & 2157 & $\mathrm{CCl}_{2}=\mathrm{C}=\mathrm{O}$ \\
\hline 2150 & 2146 & 2143 & 2148 & $\mathrm{CHCl}=\mathrm{C}=\mathrm{O}$ \\
\hline \multirow[t]{2}{*}{2138} & 2136 & 2134 & 2137 & $\mathrm{CO}$ \\
\hline & & & 2107 & $\mathrm{O}_{3} v_{1}+v_{3}^{\mathrm{a}}$ \\
\hline \multirow[t]{2}{*}{2094} & & 2090 & & ${ }^{13} \mathrm{CO}$ \\
\hline & & & 2037 & $\mathrm{CO}_{3}$ \\
\hline 1969 & & & & $\mathrm{CCO}^{\mathrm{b}}$ \\
\hline \multirow[t]{3}{*}{1878} & 1877 & 1877 & & $\mathrm{COCl}^{\mathrm{c}}$ \\
\hline & 1814 & 1809 & & gauche- $\mathrm{CHCl}_{2} \mathrm{COCl}$ \\
\hline & & & 1436 & $\mathrm{ClOO}^{\mathrm{d}}$ \\
\hline 1297 & 1296 & 1293 & & $\mathrm{CHCl}=\mathrm{C}=\mathrm{O}$ \\
\hline \multirow[t]{2}{*}{1293} & 1292 & 1291 & & $\mathrm{CCl}_{2}=\mathrm{C}=\mathrm{O}$ \\
\hline & 1262 & 1259 & & gauche- $\mathrm{CHCl}_{2} \mathrm{COCl}$ \\
\hline 1223 & 1220 & 1216 & & $\mathrm{CHCl}_{3}$ \\
\hline 1219 & 1214 & & & $\mathrm{CHCl}_{2}{ }^{\mathrm{e}}$ \\
\hline 1113 & & & & $\mathrm{CHCl}=\mathrm{C}=\mathrm{O}$ \\
\hline \multirow[t]{7}{*}{1107} & & & & $\mathrm{CHCl}=\mathrm{C}=\mathrm{O}$ \\
\hline & & & 1101 & $\mathrm{O}_{3} v_{1}{ }^{\mathrm{f}}$ \\
\hline & & 1055 & & \\
\hline & & & 1037 & $\mathrm{O}_{3} v_{3}{ }^{\mathrm{f}}$ \\
\hline & 987 & 984 & & gauche- $\mathrm{CHCl}_{2} \mathrm{COCl}$ \\
\hline & 965 & & & \\
\hline & & 954 & & $\mathrm{Xe}_{2} \mathrm{H}^{+\mathrm{g}}$ \\
\hline 934 & 932 & 932 & & $\mathrm{CCl}_{2}=\mathrm{C}=\mathrm{O}$ \\
\hline 898 & 896 & 894 & & $\mathrm{CHCl}_{2}{ }^{\mathrm{e}}$ \\
\hline \multirow[t]{4}{*}{864} & 861 & 859 & & ${ }^{13} \mathrm{CHCl}_{2}$ \\
\hline & 852 & & & $\mathrm{Kr}_{2} \mathrm{H}^{+\mathrm{g}}$ \\
\hline & & 843 & & $\mathrm{Xe}_{2} \mathrm{H}^{+\mathrm{g}}$ \\
\hline & & & 839 & $\mathrm{COCl}_{2}$ \\
\hline \multirow[t]{2}{*}{766} & 764 & 762 & & $\mathrm{CHCl}_{3}$ \\
\hline & 740 & 736 & & gauche- $\mathrm{CHCl}_{2} \mathrm{COCl}$ \\
\hline
\end{tabular}

${ }^{\mathrm{a}}$ Ref. [27]. ${ }^{\mathrm{b}}$ Ref. [24]. ${ }^{\mathrm{c}}$ Ref. [22]. ${ }^{\mathrm{d}}$ Ref. [28]. ${ }^{\mathrm{e}}$ Ref. [23]. ${ }^{\mathrm{f}}$ Ref. [26]. ${ }^{\mathrm{g}}$ Ref. [25]. 


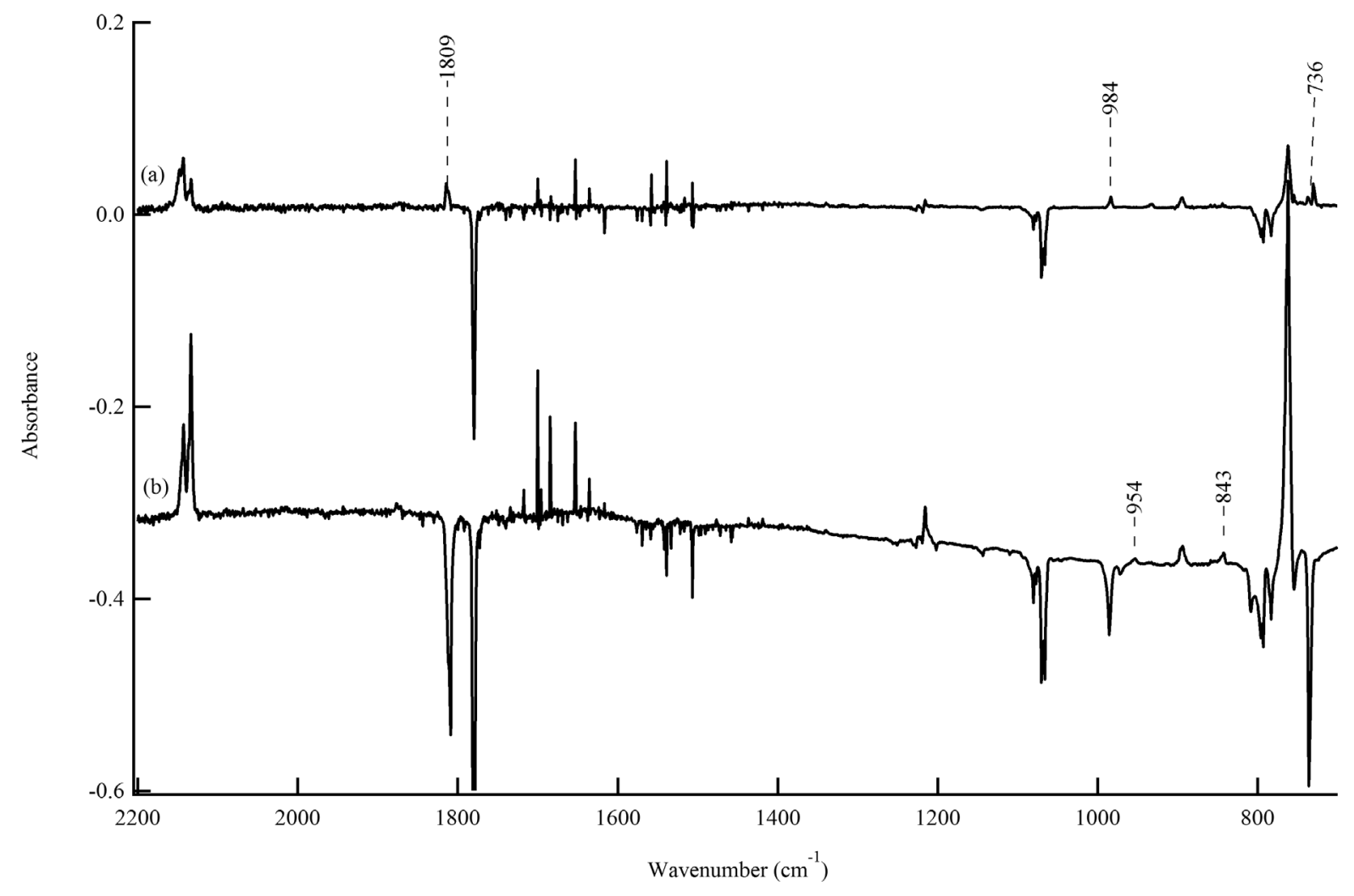

Figure 2. Infrared difference spectra upon $\lambda>253.7 \mathrm{~nm}$ irradiation of the matrix $\mathrm{CHCl}_{2} \mathrm{COCl} / \mathrm{Xe}=1 / 1000$. (a) $30-0 \mathrm{~min}$ and (b) 420 - $30 \mathrm{~min}$.

Table 2. Calculated relative electronic energies in $\mathrm{cm}^{-1}$ including zero-point vibrational energy corrections.

\begin{tabular}{ccc}
\hline Method & Difference (gauche to syn) & Barrier (syn to gauche) \\
\hline B3LYP/6-311++G(3df,3pd) & 157 & 1208 \\
B3LYP/aug-cc-pV(T+d)Z & 117 & 1161 \\
CAM-B3LYP/6-311++G(3df,3pd) & 180 & 1167 \\
CAM-B3LYP/aug-cc-pV(T+d)Z & 149 & 1186 \\
M06-2X/6-311++G(3df,3pd) & 211 & 1164 \\
M06-2X/aug-cc-pV(T+d)Z & 186 & 1316 \\
MP2/6-311++G(3df,3pd) & 225 & 1234 \\
MP2/aug-cc-pV(T+d)Z & 191 & 1239 \\
CCSD/aug-cc-pVDZ & 132 & \\
\hline
\end{tabular}

$\mathrm{CHCl}_{2} \mathrm{COCl}$ possess the different decay rates. The $\mathrm{CCl}_{2}=\mathrm{C}=\mathrm{O}$ and $\mathrm{CHCl}_{2}$ showed the growth and decay profiles. The relative yield of $\mathrm{CHCl}_{3}: \mathrm{CHCl}=\mathrm{C}=\mathrm{O}: \mathrm{CCl}_{2}=\mathrm{C}=\mathrm{O}$ at the irradiation time of 360 min was found to be 1:0.09:0.008. There is an obvious contrast as compared with the relative yield obtained in the photolysis of the matrix $\mathrm{CH}_{2} \mathrm{COCl} / \mathrm{Ar}$ where the ratio of $\mathrm{CH}_{2} \mathrm{Cl}_{2}: \mathrm{CHCl}=\mathrm{C}=\mathrm{O}$ was found to be 1:7.5 [12].

Even in $\mathrm{O}_{2}$, the ketene species were found to be produced, though the yields decreased greatly. It indicates the majority of the ketene species were formed in the triplet state by the radical mechanism. It seems plausible to explain the dominant radical mechanism in the triplet state by the enhanced intersystem crossing from $S_{1}$ caused by substitution of the chlorine atoms with methyl hydrogen atoms of acetyl chloride. Therefore, we focus on the triplet surface reaction after intersystem crossing and the ground state reaction after internal conversion. Figure 5 shows the energy diagram for the $\mathrm{CHCl}_{2} \mathrm{COCl}$ photolysis initiated by $253.7 \mathrm{~nm}$ irradiation. The photon energy at a wavelength of $253.7 \mathrm{~nm}$ corresponded to $113 \mathrm{kcal} \cdot \mathrm{mol}^{-1}$. The reaction enthalpies of three elementary reac- 

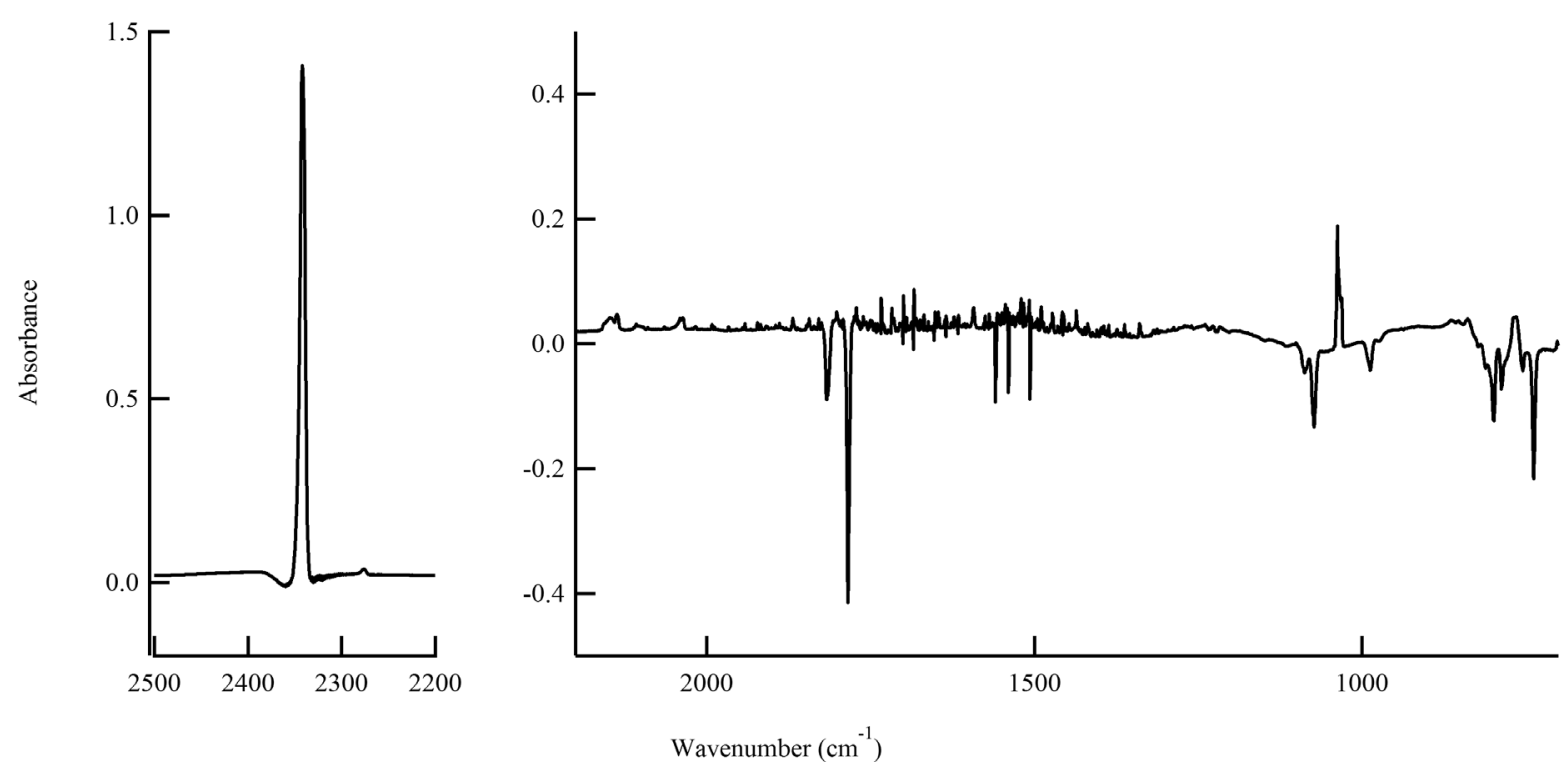

Figure 3. Infrared difference spectrum upon $\lambda>253.7 \mathrm{~nm}$ irradiation of the matrix $\mathrm{CHCl}_{2} \mathrm{COCl} / \mathrm{O}_{2}=1 / 1000$ for $480 \mathrm{~min}$.

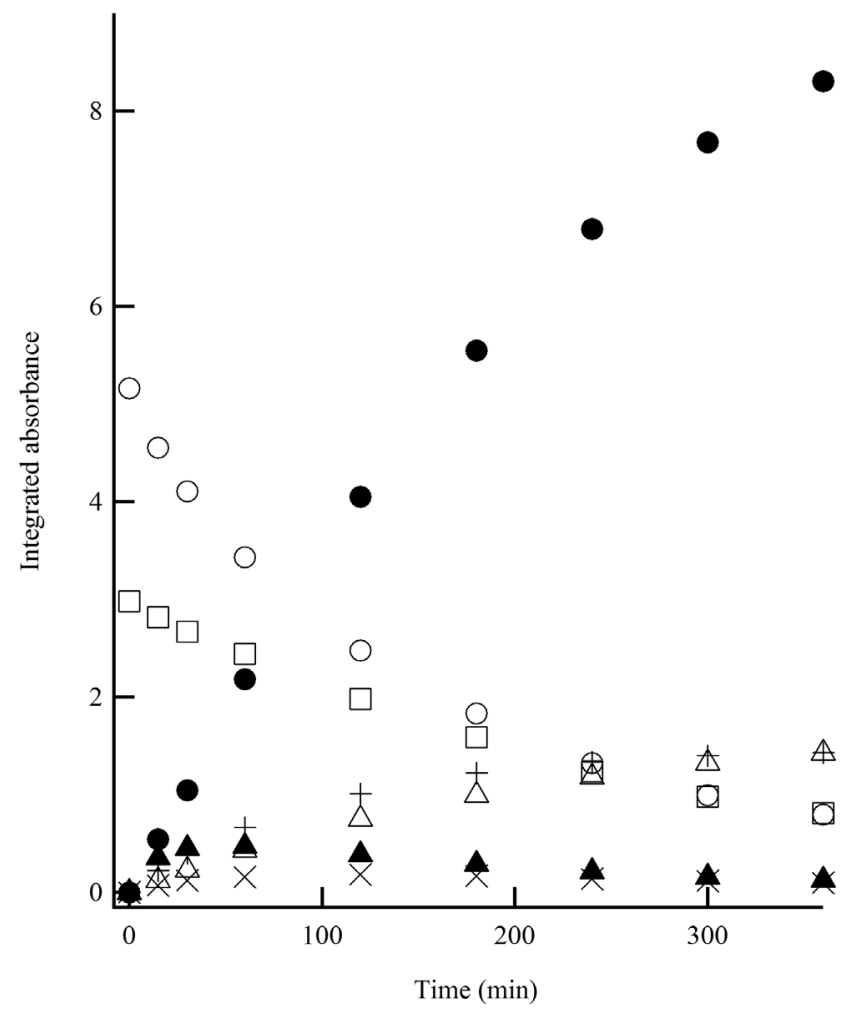

Figure 4. Integrated absorbance changes of (०) syn- $\mathrm{CHCl}_{2} \mathrm{COCl}$, ( $\left.\square\right)$ gauche$\mathrm{CHCl}_{2} \mathrm{COCl},(\bullet) \mathrm{CHCl}_{3},(+) \mathrm{CHCl}=\mathrm{C}=\mathrm{O},(\Delta) \mathrm{CO},(\boldsymbol{\Delta}) \mathrm{CCl}_{2}=\mathrm{C}=\mathrm{O}$, and $(\times)$ $\mathrm{CHCl}_{2}$ upon $\lambda>253.7 \mathrm{~nm}$ irradiation of the matrix $\mathrm{CHCl}_{2} \mathrm{COCl} / \mathrm{Ar}=1 / 1000$.

tions, $\mathrm{C}(\mathrm{O})-\mathrm{Cl}$, C-C, and $\mathrm{CHCl}-\mathrm{Cl}$ bond cleavages from the $\mathrm{T}_{1}$ equilibrium states are calculated to be -1.7 , -14.8 , and $-19.5 \mathrm{kcal} \cdot \mathrm{mol}^{-1}$ for syn- $\mathrm{CHCl}_{2} \mathrm{COCl}$ and $-2.8,-15.1$, and $-20.9 \mathrm{kcal} \cdot \mathrm{mol}^{-1}$ for gauche $-\mathrm{CHCl}_{2} \mathrm{COCl}_{\text {, }}$ respectively, where the reaction barriers are calculated to be $4.4,5.8$, and $2.6 \mathrm{kcal} \cdot \mathrm{mol}^{-1}$ for syn- $\mathrm{CHCl}_{2} \mathrm{COCl}$ and3.7, 5.6, and $2.2 \mathrm{kcal} \cdot \mathrm{mol}^{-1}$ for gauche- $\mathrm{CHCl}_{2} \mathrm{COCl}$, respectively. The C-C dissociation on the $\mathrm{T}_{1}$ surface possesses the highest barrier, while $\mathrm{CHCl}-\mathrm{Cl}$ dissociation the lowest barrier. Radical species $\mathrm{CHCl}_{2}$ and $\mathrm{COCl}$ 


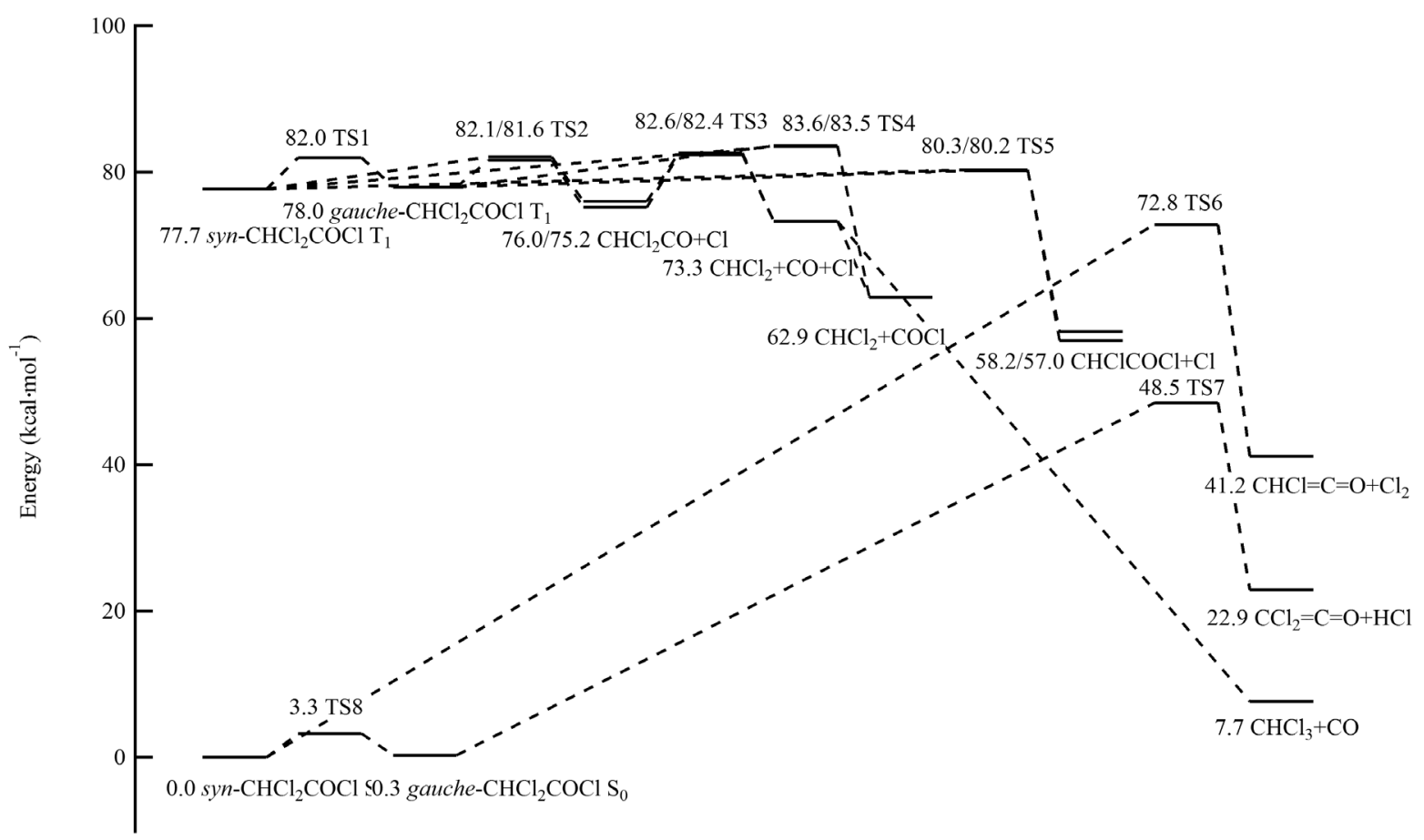

Figure 5. Energy diagram for the $\mathrm{CHCl}_{2} \mathrm{COCl}$ photolysis.

can be also produced from the dissociation of $\mathrm{CHCl}_{2} \mathrm{CO}$ into $\mathrm{CHCl}_{2}$ and $\mathrm{CO}$, followed by the recombination of $\mathrm{CO}$ with $\mathrm{Cl}$. The $\mathrm{CHClCOCl}$ would be further photodissociated. The reaction barrier for the formation of $\mathrm{CHCl}=\mathrm{C}=\mathrm{O}+\mathrm{Cl}_{2}$ in the $\mathrm{S}_{0}$ state was calculated to be higher compared with that for the formation of $\mathrm{CCl}_{2}=\mathrm{C}=\mathrm{O}$ $+\mathrm{HCl}$. The SAC-CI calculation showed the $\mathrm{S}_{1}$ and $\mathrm{T}_{1}$ states of $\mathrm{CCl}_{2}=\mathrm{C}=\mathrm{O}$ possess the mixing characters of $\pi \sigma_{\mathrm{C}-\mathrm{Cl}}^{*}$ and $\pi$ Rydberg, -0.87 (HOMO $\rightarrow$ LUMO) +0.30 (HOMO $\rightarrow$ LUMO+3). Upon UV irradiation the C-Cl bond dissociation would occur to form CCO.

For the $\mathrm{CHCl}_{2} \mathrm{COCl}$ photolysis in the rare gas matrices, the $\mathrm{C}-\mathrm{C}$ bond cleaved $\mathrm{CHCl}_{3}, \mathrm{CO}, \mathrm{CHCl}_{2}$, and $\mathrm{COCl}$ were dominantly produced similar to the $\mathrm{CCl}_{3} \mathrm{COCl}$ photolysis and contrary to the $\mathrm{CH}_{2} \mathrm{ClCOCl}$ photolysis, where ketene formation was a major process. For the $\mathrm{CHCl}_{2} \mathrm{COCl}$ photolysis in $\mathrm{O}_{2}$, both ketene and $\mathrm{CHCl}_{3}$ formations were greatly depressed, while for $\mathrm{CH}_{2} \mathrm{ClCOCl}$, the formation of ketene was slightly depressed. On the basis of these results it will be reasonable to consider that the reaction mechanism drastically changed between $\mathrm{CH}_{2} \mathrm{ClCOCl}$ and $\mathrm{CHCl}_{2} \mathrm{COCl}$ from the concerted mechanism in the $\mathrm{S}_{0}$ state to the radical mechanism in the $\mathrm{T}_{1}$ state.

\section{Conclusion}

UV light photolysis of $\mathrm{CHCl}_{2} \mathrm{COCl}$ was investigated in cryogenic $\mathrm{Ar}, \mathrm{Kr}, \mathrm{Xe}$, and $\mathrm{O}_{2}$ matrices. In $\mathrm{Ar}$, $\mathrm{Kr}$, and $\mathrm{Xe}$, the formation of $\mathrm{CHCl}_{3}$ and $\mathrm{CO}$ became the dominant process over the ketene formation. The C-C bond cleaved products $\mathrm{CHCl}_{2}$ and $\mathrm{COCl}$ were also observed. In $\mathrm{Kr}$ and Xe, photoisomerization from syn- to gauche$\mathrm{CHCl}_{2} \mathrm{COCl}$ was observed at the early stage of the irradiation. As the number of the chlorine atom substitution to methyl group of acetyl chloride increased, the C-C bond cleaved product yield in the triplet state increased, which can be attributed to an internal heavy-atom effect where the intersystem crossing rate was enhanced.

\section{Acknowledgements}

The author thanks Prof. Tsuneo Fujii and Prof. Hiromasa Nishikiori (Shinshu University) for their helpful discussions.

\section{References}

[1] Haag, W.R., Johnson, M.D. and Scofield, R. (1996) Direct Photolysis of Trichloroethene in Air: Effect of Cocontami- 
nants, Toxicity of Products, and Hydrothermal Treatment of Products. Environmental Science \& Technology, 30, 414421. http://dx.doi.org/10.1021/es950047y

[2] Oki, K., Tsuchida, S., Nishikiori, H., Tanaka, N. and Fujii, T. (2003) Photocatalytic Degradation of Chlorinated Ethenes. International Journal of Photoenergy, 5, 11-15. http://dx.doi.org/10.1155/S1110662X03000059

[3] Zuo, G.M., Cheng, Z.X., Xu, M. and Qiu, X.Q. (2003) Study on the Gas-Phase Photolytic and Photocatalytic Oxidation of Trichloroethylene. Journal of Photochemistry and Photobiology A-Chemistry, 161, 51-56. http://dx.doi.org/10.1016/S1010-6030(03)00271-5

[4] Wiltshire, K.S., Almond, M.J. and Mitchell, P.C.H. (2004) Reactions of Hydroxyl Radicals with Trichloroethene and Tetrachloroethene in Argon Matrices at 12 K. Physical Chemistry Chemical Physics, 6, 58-63. http://dx.doi.org/10.1039/b310495h

[5] Hasson, A.S. and Smith, I.W.M. (1999) Chlorine Atom Initiated Oxidation of Chlorinated Ethenes: Results for 1,1Dichloroethene $\left(\mathrm{H}_{2} \mathrm{C}=\mathrm{CCl}_{2}\right)$, 1,2-Dichloroethene $(\mathrm{HClC}=\mathrm{CClH})$, Trichloroethene $\left(\mathrm{HClC}=\mathrm{CCl}_{2}\right)$, and Tetrachloroethene $\left(\mathrm{Cl}_{2} \mathrm{C}=\mathrm{CCl}_{2}\right)$. Journal of Physical Chemistry A, 103, 2031-2043. http://dx.doi.org/10.1021/jp983583w

[6] Miyake, A., Nakagawa, I., Miyazawa, T., Ichishima, I., Shimanouchi, T. and Mizushima, S. (1958) Infra-Red and Raman Spectra of Dichloroacetyl Chloride in Relation to Rotational Isomerism. Spectrochimica Acta, 13, 161-167. http://dx.doi.org/10.1016/0371-1951(58)80073-9

[7] Woodward, A.J. and Jonathan, N. (1970) Rotational Isomerism in Dichloroacetyl Halides. Journal of Physical Chemistry, 74, 798-805. http://dx.doi.org/10.1021/j100699a022

[8] Fausto, R. and Teixeira-Dias, J.J.C. (1986) Conformational and Vibrational Spectroscopic Analusis of $\mathrm{CHCl}_{2} \mathrm{COX}_{\text {and }}$ $\mathrm{CCl}_{3} \mathrm{COX}\left(\mathrm{X}=\mathrm{Cl}, \mathrm{OH}, \mathrm{OCH}_{3}\right)$. Journal of Molecular Structure, 144, 241-263. http://dx.doi.org/10.1016/0022-2860(86)85004-9

[9] Durig, J.R., Bergana, M.M. and Phan, H.V. (1991) Conformational Stability, Barriers to Internal Rotation, Abinitio Calculations and Vibrational Assignment of Dichloroacetyl Chloride. Journal of Molecular Structure, 242, 179-205. http://dx.doi.org/10.1016/0022-2860(91)87135-5

[10] Shen, Q., Hilderbrandt, R.L. and Hagen, K. (1980) The Structure and Conformation of Dichloroacetyl Chloride. Journal of Molecular Structure, 71, 161-169. http://dx.doi.org/10.1016/0022-2860(81)85113-7

[11] Soifer, G.B. and Feshin, V.P. (2006) Molecular Structure and Conformational Transitions of Dichloroacetylchloride. Journal of Structural Chemistry, 47, 371-374. http://dx.doi.org/10.1007/s10947-006-0309-5

[12] Tanaka, N. and Nakata, M. (2014) Matrix Isolation and Theoretical Study on the Photolysis of $\mathrm{CH}_{2} \mathrm{ClCOCl}$. International Research Journal of Pure and Applied Chemistry, 4, 762-772. http://dx.doi.org/10.9734/IRJPAC/2014/12002

[13] Davidovics, G., Monnier, M. and Allouche, A. (1991) FT-IR Spectral Data and ab Initio Calculations for Haloketenes. Chemical Physics, 150, 395-403. http://dx.doi.org/10.1016/0301-0104(91)87112-9

[14] Kogure, N., Ono, T., Suzuki, E. and Watari, F. (1993) Photolysis of Matrix-Isolated Acetyl Chloride and Infrared Spectrum of the 1:1 Molecular Complex of Hydrogen Chloride with Ketene in Solid Argon. Journal of Molecular Structure, 296, 1-4. http://dx.doi.org/10.1016/0022-2860(93)80111-8

[15] Rowland, B. and Hess, W.P. (1997) UV Photochemistry of Thin Film and Matrix-Isolated Acetyl Chloride by Polarized FTIR. Journal of Physical Chemistry A, 101, 8049-8056. http://dx.doi.org/10.1021/jp9719801

[16] Tamezane, T., Tanaka, N., Nishikiori, H. and Fujii, T. (2006) Matrix Isolation and Theoretical Study on the Photolysis of Trichloroacetyl Chloride. Chemical Physics Letters, 423, 434-438. http://dx.doi.org/10.1016/j.cplett.2006.04.031

[17] Becke, A.D. (1993) Density-Functional Thermochemistry. III. The Role of Exact Exchange. Journal of Chemical Physics, 98, 5648-5652. http://dx.doi.org/10.1063/1.464913

[18] Lee, C., Yang, W. and Parr, R.G. (1988) Development of the Colle-Salvetti Correlation-Energy Formula into a Functional of the Electron Density. Physical Review B, 37, 785-789. http://dx.doi.org/10.1103/PhysRevB.37.785

[19] Yanai, T., Tew, D.P. and Handy, N.C. (2004) A New Hybrid Exchange-Correlation Functional Using the CoulombAttenuating Method (CAM-B3LYP). Chemical Physics Letters, 393, 51-57. http://dx.doi.org/10.1016/j.cplett.2004.06.011

[20] Truhlar, D.G. and Zhao, Y. (2008) The M06 Suite of Density Functionals for Main Group Thermochemistry, Thermochemical Kinetics, Noncovalent Interactions, Excited States, and Transition Elements: Two New Functionals and Systematic Testing of Four M06-Class Functionals and 12 Other Functionals. Theoretical Chemistry Accounts, 120, 215241. http://dx.doi.org/10.1007/s00214-007-0310-X

[21] Frisch, M.J., Trucks, G.W., Schlegel, H.B., Scuseria, G.E., Robb, M.A., Cheeseman, J.R., Scalmani, G., Barone, V., Mennucci, B., Petersson, G.A., Nakatsuji, H., Caricato, M., Li, X., Hratchian, H.P., Izmaylov, A.F., Bloino, J., Zheng, G., Sonnenberg, J.L., Hada, M., Ehara, M., Toyota, K., Fukuda, R., Hasegawa, J., Ishida, M., Nakajima, T., Honda, Y., Kitao, O., Nakai, H., Vreven, T., Montgomery, J.A., Peralta, J.E., Ogliaro, F., Bearpark, M., Heyd, J.J., Brothers, E., 
Kudin, K.N., Staroverov, V.N., Kobayashi, R., Normand, J., Raghavachari, K., Rendell, A., Burant, J.C., Iyengar, S.S., Tomasi, J., Cossi, M., Rega, N., Millam, N.J., Klene, M., Knox, J.E., Cross, J.B., Bakken, V., Adamo, C., Jaramillo, J., Gomperts, R., Stratmann, R.E., Yazyev, O., Austin, A.J., Cammi, R., Pomelli, C., Ochterski, J.W., Martin, R.L., Morokuma, K., Zakrzewski, V.G., Voth, G.A., Salvador, P., Dannenberg, J.J., Dapprich, S., Daniels, A.D., Farkas, Ö., Foresman, J.B., Ortiz, J.V., Cioslowski, J. and Fox, D.J. (2010) Gaussian 09, Revision B.01. Gaussian, Inc., Wallingford.

[22] Jacox, M.E. and Milligan, D.E. (1965) Matrix Isolation Study of the Reaction of Cl Atoms with CO. The Infrared Spectrum of the Free Radical ClCO. Journal of Chemical Physics, 43, 866-870. http://dx.doi.org/10.1063/1.1696861

[23] Granville, T. and Andrews, L. (1969) Matrix Infrared Spectrum and Bonding in the Dichloromethyl Radical. Journal of Chemical Physics, 50, 4235-4245. http://dx.doi.org/10.1063/1.1670888

[24] Jacox, M.E., Milligan, D.E., Moll, N.G. and Thompson, W.E. (1965) Matrix-Isolation Infrared Spectrum of the Free Radical CCO. Journal of Chemical Physics, 43, 3734-3746. http://dx.doi.org/10.1063/1.1696543

[25] Kunttu, H.M. and Seetula, J.A. (1994) Photogeneration of Ionic Species in Ar, Kr and Xe Matrices Doped with HCl, $\mathrm{HBr}$ and HI. Chemical Physics, 189, 273-292. http://dx.doi.org/10.1016/0301-0104(94)00273-8

[26] Schriver-Mazzuoli, L., de Saxcé, A., Lugez, C., Camy-Peyret, C. and Schriver, A. (1995) Ozone Generation through Photolysis of an Oxygen Matrix at $11 \mathrm{~K}$ : Fourier Transform Infrared Spectroscopy Identification of the $\mathrm{O}^{\cdots} \mathrm{O}_{3} \mathrm{Com}-$ plex and Isotopic Studies. Journal of Chemical Physics, 102, 690-701. http://dx.doi.org/10.1063/1.469181

[27] Schriver-Mazzuoli, L., Schriver, A., Lugez, C., Perrin, A., Camy-Peyret, C. and Flaud, J.M. (1996) Vibrational Spectra of the ${ }^{16} \mathrm{O} /{ }^{17} \mathrm{O} /{ }^{18} \mathrm{O}$ Substituted Ozone Molecule Isolated in Matrices. Journal of Molecular Spectroscopy, 176, 85-94. http://dx.doi.org/10.1006/jmsp.1996.0064

[28] Johnsson, K., Engdahl, A. and Nelander, B. (1993) A Matrix-Isolation Study of the ClOO Radical. Journal of Physical Chemistry, 97, 9603-9606. http://dx.doi.org/10.1021/j100140a013 
Scientific Research Publishing (SCIRP) is one of the largest Open Access journal publishers. It is currently publishing more than 200 open access, online, peer-reviewed journals covering a wide range of academic disciplines. SCIRP serves the worldwide academic communities and contributes to the progress and application of science with its publication.

Other selected journals from SCIRP are listed as below. Submit your manuscript to us via either submit@scirp.org or Online Submission Portal.
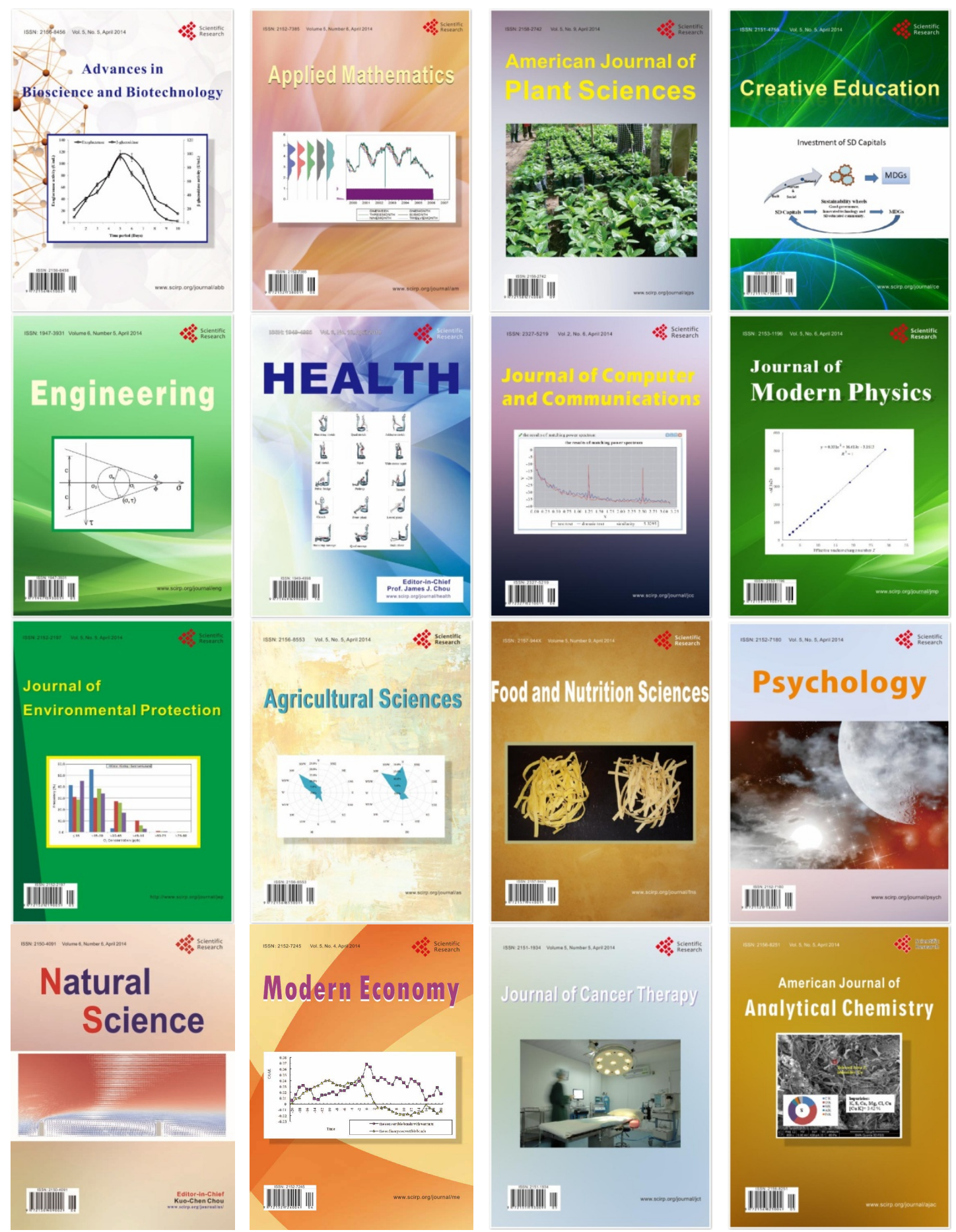